\title{
Indoor radon concentration, outdoor gamma dose rates and impact of geology in the Dhirkot area, Azad Jammu and Kashmir, sub-Himalayas, Pakistan
}

\author{
A. IQBAL ${ }^{1}$, M.S. BAIG ${ }^{2}$, M. AKRAM ${ }^{3}$, S.A. ABBASI ${ }^{1}$
}

(Manuscript received 11 May 2010, accepted 2 August 2010)

ABSTRACT The sedimentary sandstone and clay sequence of the Miocene Kamlial and Murree Formations is exposed in the sub-Himalayas of the Dhirkot area, State of Azad Jammu and Kashmir, Pakistan. The indoor radon and outdoor gamma dose rates were measured from dwellings and basement sandstone and clay rocks, respectively. The radon concentration in dwellings was $36 \pm 14 \mathrm{~Bq} \cdot \mathrm{m}^{-3}$ to $195 \pm 27 \mathrm{~Bq} \cdot \mathrm{m}^{-3}$, with an average of $121 \pm 26 \mathrm{~Bq} \cdot \mathrm{m}^{-3}$. The average radon concentration in pucka, semi-kucha and kucha houses was $124 \pm 25 \mathrm{~Bq} \cdot \mathrm{m}^{-3}, 143 \pm 25 \mathrm{~Bq} \cdot \mathrm{m}^{-3}$ and $136 \pm 26 \mathrm{~Bq} \cdot \mathrm{m}^{-3}$, respectively. The outdoor gamma dose rates for the basement sandstones and clays of the Murree Formation and Kamlial Formation were 74.0 $\pm 1.4-113.1 \pm 2.4 \mathrm{nGy} / \mathrm{h}$ and $69.6 \pm 2.2-108.8 \pm 1.4 \mathrm{nGy} / \mathrm{h}$, respectively. The average gamma dose rates for the Murree and Kamlial Formations were $91.3 \pm 14.3 \mathrm{nGy} / \mathrm{h}$. The gamma dose rate is maximum $(113.1 \pm 2.4 \mathrm{nGy} / \mathrm{h})$ and minimum $(69.6 \pm 2.2 \mathrm{nGy} / \mathrm{h})$ at higher $(5539$ feet $)$ and lower (4 493 feet) altitudes, respectively. The overall causes for the increase in average radon concentration in dwellings of the Dhirkot area were poor ventilation, old houses, humidity and temperature, cracks in houses, geology, and aggregates. The gamma dose rate variation depends on sandstone and clay lithologies, altitude and radionuclide contributions. This study shows that the average radon $(121 \pm$ $26 \mathrm{~Bq} \cdot \mathrm{m}^{-3}$ ) concentration for the inhabitants of the Dhirkot area was within the accepted safe health limit (200 Bq.m ${ }^{-3}$, ICRP, 1993; UNSCEAR, 1993).

Keywords: Isotope geology / radon / gamma dose rate / environmental radioactivity

RÉSUMÉ Concentration dans les logements, débits de dose gamma externe du radon et impact de la géologie dans la zone de Dhirkot, Azad Jammu et Cachemire, Pakistan.

La séquence de grès sédimentaire et d'argile des Formations Kamlial et Murree du Miocène est exposée dans la région sous-Himalayenne de Dhirkot, État d'Azad Jammu et Cachemire, Pakistan. Les débits de dose gamma du radon interne et externe ont été mesurées respectivement à partir des logements et du grès et des roches argileuses du sous-sol. La concentration en radon dans les logements varient de $36 \pm 14 \mathrm{~Bq} \cdot \mathrm{m}^{-3}$ à $195 \pm 27 \mathrm{~Bq} \cdot \mathrm{m}^{-3}$ avec une moyenne de $121 \pm 26 \mathrm{~Bq} \cdot \mathrm{m}^{-3}$. $\mathrm{La}^{\mathrm{a}}$ concentration moyenne de radon dans les habitations de type Pucka, Kucha et semi Kucha sont respectivement de $124 \pm 25 \mathrm{~Bq} \cdot \mathrm{m}^{-3}, 143 \pm 25 \mathrm{~Bq} \cdot \mathrm{m}^{-3}$ et $136 \pm 26 \mathrm{~Bq} \cdot \mathrm{m}^{-3}$. Les débits de dose de rayonnement gamma externe pour les sous-sols en grès et argiles de la formation Murree et de la formation Kamlial varient respectivement de

Department of Physics, University of Azad Jammu and Kashmir, Muzaffarabad, Pakistan.

Institute of Geology, University of Azad Jammu and Kashmir, Muzaffarabad, Pakistan.

Physics Research Division, PINSTECH, P.O. Nilore, Islamabad, Pakistan. 
$74,0 \pm 1,4$ à $113,1 \pm 2,4 \mathrm{nGy} / \mathrm{h}$ et de $69,6 \pm 2,2$ à $108,8 \pm 1,4 \mathrm{nGy} / \mathrm{h}$. Le taux moyen de dose gamma pour les formations Murree et Kamlial est de $91,3 \pm 14,3 \mathrm{nGy} / \mathrm{h}$. Le débit de dose gamma est maximal $(113,1 \pm 2,4 \mathrm{nGy} / \mathrm{h})$ pour une altitude élevée (5 539 pieds) et minimal $(69,6 \pm 2,2 \mathrm{nGy} / \mathrm{h}$ ) pour une altitude basse (4 493 pieds). Les causes de l'augmentation globale de la concentration moyenne de radon dans les habitations de la zone Dhirkot sont une mauvaise ventilation, de vieilles maisons, l'humidité et la température, les fissures dans les maisons, la géologie et des agrégats. La variation des débits de dose gamma dépend de la lithologie des grès et des argiles, de l'altitude et des contributions des radionucléides. Cette étude montre que la concentration moyenne en radon $\left(121 \pm 26 \mathrm{~Bq} \cdot \mathrm{m}^{-3}\right)$ pour les habitants de la zone Dhirkot est inférieure à la limite de sécurité sanitaire acceptée (200 Bq.m ${ }^{-3}, I_{\text {ICRP, }}$ 1993 ; UNSCEAR, 1993).

\section{Introduction}

Dhirkot is a tourist summer resort in the State of Azad Jammu and Kashmir, subHimalayas, northeast Pakistan. Dhirkot is a tehsil (subdivision) of District Bagh, Azad Jammu and Kashmir, and is located at a distance of $132 \mathrm{~km}$ from Islamabad, the capital of Pakistan, via Kohala. The area represents the mountainous terrain and high relief topography. The altitude varies from 1676-2 $000 \mathrm{~m}$. The summer and winter temperatures are $25-35^{\circ} \mathrm{C}$ and $-5-5{ }^{\circ} \mathrm{C}$, respectively. The mean annual rainfall is $2400-2850 \mathrm{~mm}$. The humidity of the area is $100 \%$. The climate varies from tropical to temperate. It is pleasant during summer and extremely cold in winter.

Radon gas emanates by the decay of naturally occurring uranium found in almost all rocks and soils. Radon moves from its source in rocks and soil through voids and fractures, and its concentration values vary with the specific site and geological material. The inhalation of radon in dwellings is one of the most important sources of radon exposure to inhabitants. The exposure to radiation from radon and the lung cancer risks to inhabitants are dependent on the radon level in the houses. This study deals with the measurement of radon levels in the dwellings of Dhirkot and its surrounding areas by using the solid state nuclear track detector technique (Fleischer et al., 1975; Tufail and Ahmad, 1992; Vaupotic et al., 1994; Akram et al., 2005; Majvorn, 1986).

The local pucka, semi-kucha and kucha houses terminology was used during this investigation (Iqbal et al., 2007a, 2007b). The dwellings constructed of concrete beam and pillar structures, concrete blocks, mudstone, bricks and sandstone with external and internal cement plaster, with roofs of concrete or aerated GIS sheets, are known as pucka houses. The semi-kucha houses are made of sandstone, mudstone and concrete blocks with external and internal cement plaster, with mud and timber roofs. The houses constructed of mud, mudstone and sandstone with external and internal mud plaster, with wooden and mud roofs, are referred to as kucha houses. The kucha and semi-kucha houses are poorly ventilated; in contrast, 
the pucka houses are well ventilated. The sandstones of the Murree and Kamlial Formations have been used in the construction of pucka, semi-kucha and kucha houses. The clays of the Murree and Kamlial Formations are used in construction of kucha houses. However, construction materials used in pucka and semi-kucha houses are the limestone and sandstone aggregates. The limestone aggregate is from the Margalla Hills of Pakistan. The sandstone aggregate is from the Murree Formation and Kamlial Formation. The clays of the upper Soan Formation have been used in the red bricks of the pucka and semi-kucha houses. The sand used in concrete is from the Mahal River, Jhelum River and Indus River.

Cosmic and terrestrial radiation is the natural source for external radiation exposures. The primordial $\left({ }^{40} \mathrm{~K},{ }^{232} \mathrm{Th}\right.$ and $\left.{ }^{238} \mathrm{U}\right)$ and cosmogenic $\left({ }^{3} \mathrm{H},{ }^{7} \mathrm{Be}\right.$ and $\left.{ }^{14} \mathrm{C}\right)$ radionuclides produce natural radiation. The natural background radiation due to the presence of these primordial radionuclides contributes exposure to human beings (UNSCEAR, 2000). In the present study we determined the distribution of dose rates from terrestrial gamma radiation. The radon concentrations in dwellings and gamma dose rates are correlated with the rock lithologies of the Dhirkot area.

\section{Geology}

The sedimentary rocks have been deformed due to the Tertiary Himalayan collision in the Dhirkot area of the State of Azad Jammu and Kashmir, subHimalaya, Pakistan (Fig. 1; Akhtar et al., 2004). The area is folded, faulted, jointed and fractured. The major structures are the Chamiati syncline and Dhirkot fault. The areas along the Dhirkot Fault were fractured due to strong ground shaking during the October 8th, 2005 Kashmir earthquake (Baig, 2006). These structures provide passages for the migration of radon gas to the surface.

The rock units exposed in the Chamiati syncline are the Murree and Kamlial Formations. The Murree Formation consists of fine to medium grained gray sandstone, red, khaki and gray clays and local conglomerate layers. The Kamlial Formation includes the blue-gray, khaki and gray medium to coarse grained sandstones with alternating red, reddish, reddish-brown, khaki and khaki-brown clays and local conglomerate layers. These rocks are the molasse of the Himalayan orogeny (Wadia, 1928, 1931; Baig and Lawrence, 1987; Baig, 1991).

\section{Material and method}

The radon data were collected during summer (July-September) for 65 days from the houses located on the sedimentary rocks of the Murree and Kamlial Formations (Fig. 1). The radon concentration measurements were made in various houses of the Dhirkot area using CN 85-type plastic track detectors. The measurements were 


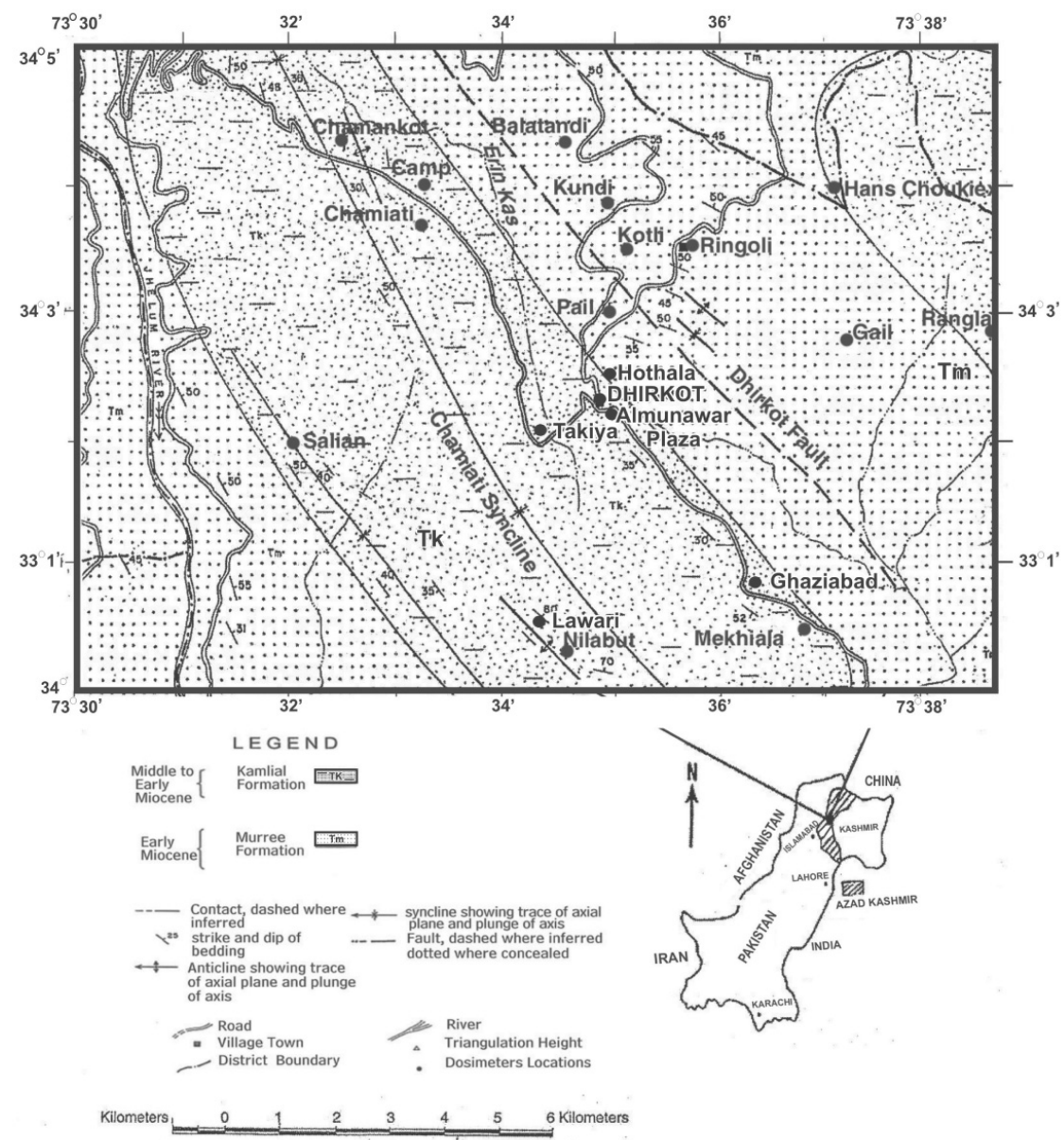

Figure 1 - The geological map showing dosimeters location in Dhirkot area Azad kashmir Pakistan (Modified after Akhtar et al., 2004).

Carte géologique montrant l'emplacement des dosimètres à Dhirkot région de Azad, Cachemire, Pakistan (modifié d'après Akhtar et al., 2004).

based on passive detection of radon (Fleischer et al., 1975). The box-type dosimeters made up of a plastic frame, as shown in Figure 2, were used. The dosimeters were suspended inside the rooms at a height of $2.5 \mathrm{~m}$ from the floor. The dosimeters were exposed to radon for 65 days and after retrieval were etched chemically with $6.25 \mathrm{~N} \mathrm{NaOH}$ and scanned in the laboratory using an optical microscope at $400 \mathrm{x}$ magnification for the determination of track density. The recorded track density was converted into Bq. $\mathrm{m}^{-3}$ by using a calibration factor 


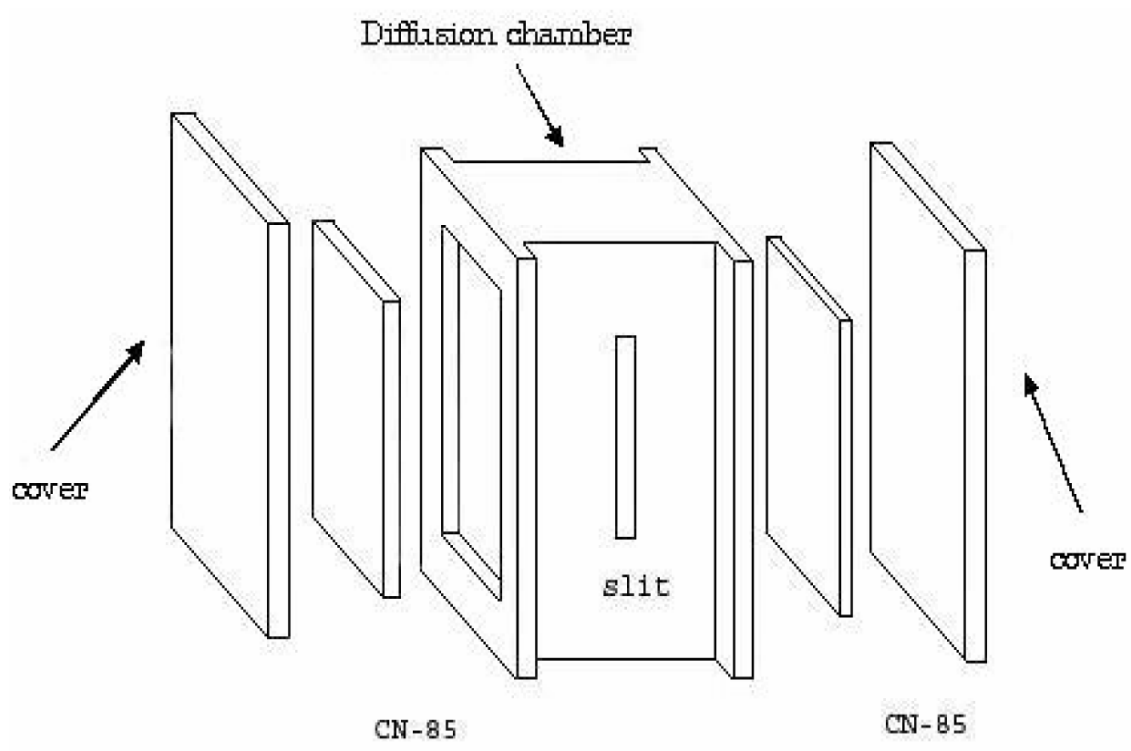

Figure 2 - Schematic diagram of box type dosimeter.

Schéma d'un dosimétre type boûte.

for $\mathrm{CN}-85$ detectors in box-type dosimeters as 0.0092 tracks $\mathrm{cm}^{-2} \mathrm{~h}^{-1}$ equal to 1 Bq.m ${ }^{-3}$ of ${ }^{222} \mathrm{Rn}$ (Tufail and Ahmad, 1992; Akram et al., 2005; Tufail et al., 1992; Iqbal et al., 2007a, 2007b).

The ambient outdoor gamma survey measurements were taken in air one meter above ground at different locations (Tab. I) using a portable radiometric instrument, Ludlum 19, which utilizes an internally mounted $\mathrm{Na} \mathrm{I}\left(\mathrm{T}_{\mathrm{I}}\right)$ scintillator for measuring gamma radiation. The exposure rate measured in $\mu \mathrm{Rh}^{-1}$ was converted into absorbed dose rate $\mathrm{nGy} / \mathrm{h}$ using the conversion factor of $1 \mu \mathrm{Rh}^{-1}=8.7 \mathrm{nGy} / \mathrm{h}$. (Sannapa et al., 2003; Kam and Ahmet, 2007). The readings are represented in terms of $\mathrm{nGy} / \mathrm{h}$.

\section{Results and discussion}

The radon concentration was measured in houses of the Dhirkot area, State of Azad Jammu and Kashmir, Pakistan. The radon data and locations are presented in Table II and Figure 1, respectively. The radon concentration in the Dhirkot area was $36 \pm 14 \mathrm{~Bq} \cdot \mathrm{m}^{-3}$ to $195 \pm 27 \mathrm{~Bq} \cdot \mathrm{m}^{-3}$, with an average concentration of $121 \pm 26 \mathrm{~Bq} \cdot \mathrm{m}^{-3}$. The maximum and minimum radon concentrations in Kucha houses were $168 \pm 29 \mathrm{~Bq} \cdot \mathrm{m}^{-3}$ and $62 \pm 18 \mathrm{~Bq} \cdot \mathrm{m}^{-3}$, respectively. The semi-kucha 
TABLE I

Outdoor gamma dose rates in the Dhirkot area, Azad Jammu and Kashmir, Pakistan. Débit de dose gamma externe dans la région de Dhirkot, Azad Jammu et Cachemire, Pakistan.

\begin{tabular}{|c|c|c|c|c|c|c|}
\hline \multirow[t]{2}{*}{ Place } & \multicolumn{2}{|c|}{ Location } & \multirow{2}{*}{$\begin{array}{l}\text { Altitude } \\
\text { (Feet) }\end{array}$} & \multirow{2}{*}{$\begin{array}{l}\text { Gamma } \\
\text { dose rate } \\
(\mathrm{nGy} / \mathrm{h})\end{array}$} & \multirow{2}{*}{$\begin{array}{l}\text { Geological } \\
\text { Formation }\end{array}$} & \multirow[t]{2}{*}{ Lithology } \\
\hline & North & East & & & & \\
\hline Lawari & $34^{\circ} 01.130^{\prime}$ & $073^{0} 34.777^{\prime}$ & 6156 & $104.4 \pm 2.3$ & Kamlial & $\begin{array}{l}\text { Dominant blue-gray to khaki- } \\
\text { gray sandstones with } \\
\text { subordinate khaki-brown } \\
\text { clays }\end{array}$ \\
\hline Dhirkot & $34^{\circ} 02.147^{\prime}$ & $073^{\circ} 34.752^{\prime}$ & 5259 & $78.3 \pm 2.2$ & Kamlial & $\begin{array}{l}\text { Sandstone with red and khaki } \\
\text { clays }\end{array}$ \\
\hline Salian & $34^{\circ} 02.281^{\prime}$ & $073^{\circ} 33.431^{\prime}$ & 5867 & $104.4 \pm 1.6$ & Kamlial & $\begin{array}{l}\text { Khaki gray sandstone with } \\
\text { subordinate clays }\end{array}$ \\
\hline Dhirkot & $34^{\circ} 02.074^{\prime}$ & $073^{\circ} 34.948^{\prime}$ & 5188 & $82.7 \pm 0.9$ & Kamlial & $\begin{array}{l}\text { Reddish to reddish-brown and } \\
\text { khaki clays with subordinate } \\
\text { khaki-brown to blue-gray } \\
\text { sandstones }\end{array}$ \\
\hline $\begin{array}{l}\text { Almunawar } \\
\text { Plaza }\end{array}$ & $34^{\circ} 02.171^{\prime}$ & $073^{\circ} 34.833^{\prime}$ & 5344 & $108.8 \pm 1.4$ & Kamlial & $\begin{array}{l}\text { Reddish to reddish-brown and } \\
\text { khaki clays with subordinate } \\
\text { khaki-brown to blue-gray } \\
\text { sandstones }\end{array}$ \\
\hline Takyia & $34^{\circ} 02.530^{\prime}$ & $073^{\circ} 34.400^{\prime}$ & 5310 & $87.0 \pm 4.1$ & Kamlial & $\begin{array}{l}\text { Reddish to reddish-brown and } \\
\text { khaki clays with subordinate } \\
\text { khaki-brown to blue-gray } \\
\text { sandstones }\end{array}$ \\
\hline Chamankot & $34^{\circ} 04.177^{\prime}$ & $073^{\circ} 32.034^{\prime}$ & 4826 & $95.7 \pm 1.6$ & Kamlial & $\begin{array}{l}\text { Red to reddish clays with thin } \\
\text { layers of sandstones }\end{array}$ \\
\hline Chamiati & $34^{\circ} 03.908^{\prime}$ & $073^{\circ} 32.801^{\prime}$ & 4493 & $69.6 \pm 2.2$ & Kamlial & $\begin{array}{l}\text { Dominant red to reddish clays } \\
\text { with subordinate khaki-gray } \\
\text { sandstones }\end{array}$ \\
\hline Pail & $34^{\circ} 02.530^{\prime}$ & $073^{\circ} 34.400^{\prime}$ & 5283 & $87.0 \pm 2.04$ & Murree & $\begin{array}{l}\text { Khaki clays with occasional } \\
\text { sandstone layers }\end{array}$ \\
\hline Kotli & $34^{\circ} 03.380^{\prime}$ & $073^{\circ} 34.530^{\prime}$ & 5539 & $113.1 \pm 2.4$ & Murree & $\begin{array}{l}\text { Dominant red to gray clays } \\
\text { with patches of gray } \\
\text { sandstones }\end{array}$ \\
\hline Kundi & $34^{\circ} 03.327^{\prime}$ & $073^{\circ} 34.524^{\prime}$ & 5610 & $91.4 \pm 1.4$ & Murree & $\begin{array}{l}\text { Red to red gray clays with } \\
\text { subordinate sandstones }\end{array}$ \\
\hline Hothala & $34^{\circ} 02.058^{\prime}$ & $073^{\circ} 34.998^{\prime}$ & 5139 & $74.0 \pm 1.4$ & Murree & $\begin{array}{l}\text { Dominant khaki-brown to red } \\
\text { clays with gray sandstones. }\end{array}$ \\
\hline
\end{tabular}

houses had maximum radon concentration of $195 \pm 27 \mathrm{~Bq} \cdot \mathrm{m}^{-3}$ and minimum radon concentration of $103 \pm 24 \mathrm{~Bq} \cdot \mathrm{m}^{-3}$. In contrast, the pucka houses had maximum and minimum radon concentrations of $168 \pm 29 \mathrm{~Bq} \cdot \mathrm{m}^{-3}$ and $36 \pm 14 \mathrm{~Bq} \cdot \mathrm{m}^{-3}$, respectively. 
TABLE II

The radon data from the dwellings of the Dhirkot area, Azad Jammu and Kashmir, Pakistan. Données sur le radon dans les habitations de la zone de Dhirkot, Azad Jammu and Cachemire, Pakistan.

\begin{tabular}{|c|c|c|c|c|c|}
\hline $\begin{array}{l}\text { Sr. } \\
\text { No. }\end{array}$ & $\begin{array}{l}\text { Detector } \\
\text { No. }\end{array}$ & Location & $\begin{array}{l}\text { Location of the } \\
\text { detector in house }\end{array}$ & $\begin{array}{c}\text { Track } \\
\text { density }\end{array}$ & $\begin{array}{c}\text { Radon concentration } \\
\text { Bq. } \mathbf{m}^{-3}\end{array}$ \\
\hline \multicolumn{6}{|c|}{ 1.Pucka Houses } \\
\hline 1 & $\mathrm{~T}-7$ & Dhirkot City Center & Bedroom & $1.12 \pm 0.19$ & $168 \pm 29$ \\
\hline 2 & $\mathrm{~T}-8$ & Dhirkot City Center & Bedroom & $0.96 \pm 0.18$ & $144 \pm 27$ \\
\hline 3 & T-9 & Almnawar plaza (Dhirkot) & Bedroom & $0.61 \pm 0.14$ & $93 \pm 22$ \\
\hline 4 & $\mathrm{~T}-10$ & Almnawar plaza (Dhirkot) & Bedroom & $0.58 \pm 0.14$ & $88 \pm 21$ \\
\hline 5 & $\mathrm{~T}-21$ & Dhirkot Market & Bedroom & $0.73 \pm 0.18$ & $109 \pm 27$ \\
\hline 6 & $\mathrm{~T}-22$ & Dhirkot Market & Bedroom & $0.77 \pm 0.18$ & $116 \pm 27$ \\
\hline 7 & $\mathrm{~T}-15$ & Pail & Bedroom & $0.98 \pm 0.18$ & $149 \pm 27$ \\
\hline 8 & $\mathrm{~T}-16$ & Pail & Bedroom & $1.04 \pm 0.19$ & $157 \pm 28$ \\
\hline 9 & $\mathrm{~T}-17$ & Pail & Kitchen & $1.07 \pm 0.18$ & $162 \pm 28$ \\
\hline 10 & $\mathrm{~T}-18$ & Pail & Kitchen & $0.77 \pm 0.16$ & $116 \pm 24$ \\
\hline 11 & $\mathrm{~T}-27$ & Chamiati & Bedroom & $0.96 \pm 0.18$ & $144 \pm 27$ \\
\hline 12 & $\mathrm{~T}-28$ & Chamiati (Gahl) & Bedroom & $1.02 \pm 0.21$ & $154 \pm 32$ \\
\hline 13 & $\mathrm{~T}-41$ & Chamiati & Kitchen & $0.70 \pm 0.16$ & $106 \pm 24$ \\
\hline 14 & $\mathrm{~T}-42$ & Chamiati & Kitchen & $0.85 \pm 0.17$ & $129 \pm 26$ \\
\hline 15 & $\mathrm{~T}-45$ & Chamiati & Bedroom & $0.55 \pm 0.15$ & $84 \pm 23$ \\
\hline 16 & T-39 & Camp & Bedroom & $0.51 \pm 0.15$ & $77 \pm 22$ \\
\hline 17 & $\mathrm{~T}-40$ & Camp & Bedroom & $0.77 \pm 0.18$ & $117 \pm 27$ \\
\hline 18 & $\mathrm{~T}-46$ & Camp & Bedroom & $0.85 \pm 0.17$ & $129 \pm 26$ \\
\hline 19 & $\mathrm{~T}-54$ & Rangla & Bedroom & $0.99 \pm 0.19$ & $149 \pm 29$ \\
\hline 20 & $\mathrm{~T}-56$ & Rangla & Bedroom & $0.97 \pm 0.18$ & $147 \pm 28$ \\
\hline 21 & $\mathrm{~T}-53$ & Chaman Kot & Bedroom & $0.24 \pm 0.09$ & $36 \pm 14$ \\
\hline 22 & $\mathrm{~T}-55$ & Ghaziabad & Bedroom & $0.86 \pm 0.17$ & $134 \pm 26$ \\
\hline 23 & $\mathrm{~T}-57$ & Rangoli & Bedroom & $0.76 \pm 0.17$ & $144 \pm 26$ \\
\hline \multicolumn{6}{|c|}{ Average radon concentration pucka houses $=124 \pm 25 \mathrm{~Bq} \cdot \mathrm{m}^{-3}$} \\
\hline \multicolumn{6}{|c|}{ 2.Semi-Kucha Houses } \\
\hline 24 & $\mathrm{~T}-3$ & Nilabut & Bedroom & $0.85 \pm 0.17$ & $129 \pm 26$ \\
\hline 25 & $\mathrm{~T}-4$ & Nilabut & Bedroom & $0.96 \pm 0.18$ & $144 \pm 27$ \\
\hline 26 & $\mathrm{~T}-5$ & Nilabut & Bedroom & $0.75 \pm 0.16$ & $113 \pm 24$ \\
\hline 27 & T-6 & Nilabut & Bedroom & $0.96 \pm 0.18$ & $144 \pm 27$ \\
\hline 28 & $\mathrm{~T}-13$ & Nilabut & Bedroom & $0.96 \pm 0.18$ & $144 \pm 27$ \\
\hline 29 & $\mathrm{~T}-14$ & Nilabut & Bedroom & $0.89 \pm 0.17$ & $134 \pm 26$ \\
\hline 30 & T-29 & Kotli & Bedroom & $0.99 \pm 0.18$ & $149 \pm 28$ \\
\hline
\end{tabular}


A. IQBAL et al.

TABLE II Continued.

\begin{tabular}{|c|c|c|c|c|c|}
\hline $\begin{array}{l}\text { Sr. } \\
\text { No. }\end{array}$ & $\begin{array}{l}\text { Detector } \\
\text { No. }\end{array}$ & Location & $\begin{array}{l}\text { Location of the } \\
\text { detector in house }\end{array}$ & $\begin{array}{l}\text { Track } \\
\text { density }\end{array}$ & $\begin{array}{l}\text { Radon concentration } \\
\text { Bq. } \mathbf{m}^{-3}\end{array}$ \\
\hline 31 & $\mathrm{~T}-30$ & Kotli & Bedroom & $0.94 \pm 0.19$ & $143 \pm 29$ \\
\hline 32 & $\mathrm{~T}-31$ & Kotli & Kitchen & $0.78 \pm 0.16$ & $118 \pm 25$ \\
\hline 33 & $\mathrm{~T}-32$ & Kotli & Kitchen & $0.89 \pm 0.18$ & $132 \pm 27$ \\
\hline 34 & $\mathrm{~T}-33$ & Kotli & Bedroom & $1.24 \pm 0.18$ & $187 \pm 28$ \\
\hline 35 & $\mathrm{~T}-34$ & Kotli & Bedroom & $1.25 \pm 0.20$ & $182 \pm 30$ \\
\hline 36 & $\mathrm{~T}-35$ & Kotli & Kitchen & $0.68 \pm 0.16$ & $103 \pm 24$ \\
\hline 37 & $\mathrm{~T}-36$ & Kotli & Kitchen & $1.01 \pm 0.18$ & $152 \pm 26$ \\
\hline 38 & $\mathrm{~T}-37$ & Balatandi & Bedroom & $0.77 \pm 0.18$ & $116 \pm 7$ \\
\hline 39 & $\mathrm{~T}-38$ & Balatandi & Bedroom & $0.96 \pm 0.18$ & $144 \pm 27$ \\
\hline 40 & $\mathrm{~T}-51$ & Lawari & Bedroom & $1.29 \pm 0.18$ & $195 \pm 27$ \\
\hline \multicolumn{6}{|c|}{ Average radon concentration semi-kucha houses $=143 \pm 25$ Bq. $\mathrm{m}^{-3}$} \\
\hline \multicolumn{6}{|c|}{ 3.Kucha Houses } \\
\hline 41 & $\mathrm{~T}-11$ & Takyia & Bedroom & $1.08 \pm 0.19$ & $163 \pm 28$ \\
\hline 42 & $\mathrm{~T}-12$ & Dhirkot & Bedroom & $0.96 \pm 0.18$ & $144 \pm 27$ \\
\hline 43 & $\mathrm{~T}-23$ & Salian & Bedroom & $1.09 \pm 0.19$ & $165 \pm 29$ \\
\hline 44 & $\mathrm{~T}-24$ & Salian & Bedroom & $0.90 \pm 0.17$ & $136 \pm 26$ \\
\hline 45 & $\mathrm{~T}-25$ & Chamiati & Bedroom & $0.83 \pm 0.19$ & $126 \pm 28$ \\
\hline 46 & $\mathrm{~T}-26$ & Chamiati & Bedroom & $0.92 \pm 0.18$ & $139 \pm 27$ \\
\hline 47 & $\mathrm{~T}-43$ & Kundi & Bedroom & $1.12 \pm 0.19$ & $168 \pm 29$ \\
\hline 48 & $\mathrm{~T}-44$ & Kundi & Bedroom & $0.41 \pm 0.12$ & $62 \pm 18$ \\
\hline 49 & $\mathrm{~T}-52$ & Salian & Bedroom & $0.81 \pm 0.19$ & $122 \pm 28$ \\
\hline \multicolumn{6}{|c|}{ Average radon concentration kucha houses $=136 \pm 26 \mathrm{~Bq} \cdot \mathrm{m}^{-3}$} \\
\hline
\end{tabular}

Minimum radon concentration $=36 \pm 14 \mathrm{~Bq} \cdot \mathrm{m}^{-3}$, Maximum radon concentration $=195 \pm 27 \mathrm{~Bq} \cdot \mathrm{m}^{-3}$, Average radon concentration $=121 \pm 26 \mathrm{~Bq} \cdot \mathrm{m}^{-3}$.

The average radon concentration in pucka, semi-kucha and kucha houses were $124 \pm 25 \mathrm{~Bq} \cdot \mathrm{m}^{-3}, 143 \pm 25 \mathrm{~Bq} \cdot \mathrm{m}^{-3}$ and $136 \pm 26 \mathrm{~Bq} \cdot \mathrm{m}^{-3}$, respectively. The semi-kucha houses had relatively higher average radon concentration (143 \pm 25 Bq. $\left.{ }^{-3}\right)$ than kucha houses $\left(136 \pm 26 \mathrm{~Bq} \cdot \mathrm{m}^{-3}\right)$ and pucka houses $(124 \pm$ $\left.25 \mathrm{~Bq} \cdot \mathrm{m}^{-3}\right)$. The average radon concentration decreases from semi-kucha to pucka houses $\left(143 \pm 25 \mathrm{~Bq} \cdot \mathrm{m}^{-3}\right.$ to $\left.124 \pm 25 \mathrm{~Bq} \cdot \mathrm{m}^{-3}\right)$. The elevated indoor radon concentrations in houses made of mud as compared with pucka cement houses has also been reported in earlier studies (Choubey et al., 1997; Khan et al., 2008; Singh 
Pucka Semi-Kucha Kucha

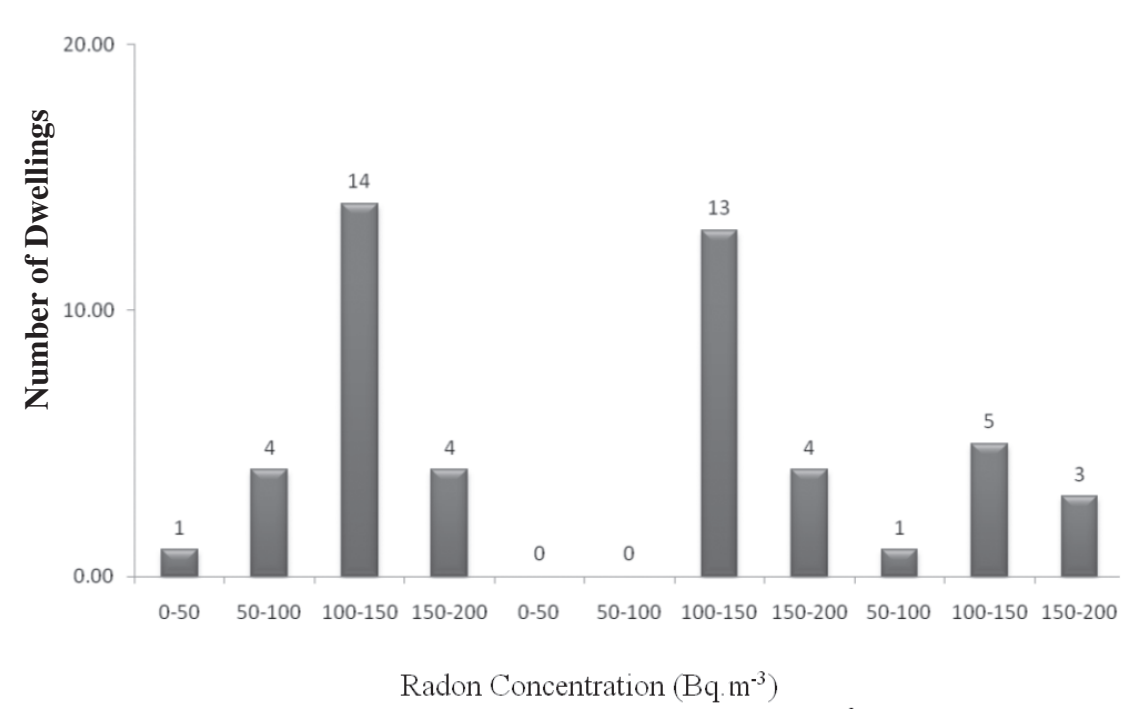

Figure 3 - Frequency distribution of radon concentration (Bq. $\left.{ }^{-3}\right)$ in Pucka, Semi-Kucha and Kucha dwellings of the Dhirkot area, Azad Kashmir, Pakistan.

Distribution des concentrations de radon (Bq. $\left.\mathrm{m}^{-3}\right)$ dans les habitations de type Pucka SemiKucha et Kucha dans la zone de Dhirkot, Azad Cachemire, Pakistan.

et al., 2005b). Figure 3 shows the frequency distribution of radon concentration $\left(\right.$ Bq. $\left.\mathrm{m}^{-3}\right)$ in pucka, semi-kucha and kucha dwellings. The radon concentrations 100-150 Bq. $\mathrm{m}^{-3}, 150-200 \mathrm{~Bq} \cdot \mathrm{m}^{-3}, 50-100 \mathrm{~Bq} \cdot \mathrm{m}^{-3}$ and $0-50 \mathrm{~Bq} \cdot \mathrm{m}^{-3}$ were $60 \%$, $17 \%, 17 \%$ and $4 \%$ in Pucka houses, respectively. The $100-150$ Bq. ${ }^{-3}$ and $150-(<200)$ Bq. $\mathrm{m}^{-3}$ radon levels were $76 \%$ and $24 \%$ in semi-Kucha houses, respectively. The radon in the ranges $100-150 \mathrm{~Bq} \cdot \mathrm{m}^{-3}, 150-(<200) \mathrm{Bq} \cdot \mathrm{m}^{-3}$ and $50-100 \mathrm{~Bq} \cdot \mathrm{m}^{-3}$ was recorded at $55 \%, 33 \%$ and $11 \%$ in kucha houses, respectively. However, the maximum radon level $150-(<200) \mathrm{Bq} \cdot \mathrm{m}^{-3}$ is $17 \%, 23 \%$ and $33 \%$ in pucka, semi-kucha and kucha houses, respectively. The variation in radon frequency distribution is attributed to the construction material used, ventilation and geological structures. The radon values that are on the higher side were found in the Kotli, Dhirkot and Pail locations and these higher values may be attributed to the nearness of these places to the Dhirkot fault (Fig. 1). Radon enters houses from joints and cracks, thus increasing the indoor radon levels. The maximum value $\left(195 \pm 27\right.$ Bq. $\left.{ }^{-3}\right)$ was measured in Lawari that is at a height of 6156 feet. This maximum value may be due to comparatively reduced ventilation because of lower temperature at high altitude and also small cracks observed in the floor of 
this house. This site is in the Kamlial formation and the lithology consists of dominate blue-gray to khaki-gray sandstones with subordinate khaki-brown clays. The gamma dose rate value $(104.4 \pm 2.3 \mathrm{nGy} / \mathrm{h})$ at this location was also found to be on the higher side.

The average radon concentration (in pucka, semi-kucha and kucha houses, Tab. II) from $124 \pm 25$ Bq. $\mathrm{m}^{-3}$ to $143 \pm 25 \mathrm{~Bq} \cdot \mathrm{m}^{-3}$ in the Dhirkot area was higher than the average radon concentration for Mirpur, Gujaranwala, Muktsar and Ferozepur districts, the cities of Lucknow and Kanpur, Kumaun, Taiwan and Mexico city (Iqbal et al., 2008; Khan et al., 1997; Singh et al., 2005a; Khan, 2000; Ramola et al., 2005; Choubey et al., 2003; Iimoto et al., 2001; Franco-Marina et al., 2003) in Pakistan, India, Taiwan and Mexico. The radon concentration in Bangladesh and Parvati valley, Hamirpur, Utter Pradesh and Brahmaputra valley, Assam, in India have been reported to range from $49 \pm 13-835 \pm 23$ Bq.m ${ }^{-3}$, 193-356 Bq.m ${ }^{-3}, 260.51-724.29$ Bq.m ${ }^{-3}, 19.4-2782$ Bq.m ${ }^{-3}$ and $35-215 \mathrm{~Bq} \cdot \mathrm{m}^{-3}$, respectively (Khan and Chowdhury, 2008; Choubey et al., 1997; Singh et al., 2005b; Khan et al., 2008; Deka et al., 2003). The 36 $\pm 14-195 \pm 27$ Bq.m ${ }^{-3}$ radon range in Dhirkot is lower than the radon concentration range of the abovementioned countries. The overall causes for the higher average radon concentration in dwellings of the Dhirkot area are; (1) old houses, (2) cracks, (3) fissures and fractures in the basement of houses, (4) nearness to the Dhirkot Fault, (5) poor ventilation, (6) humidity and temperature, (7) aggregates, and (8) the presence of open fractures along the fold axes and faults. The fractures provide passages for the migration of radon gas to the surface. The radon concentration in the Dhirkot area was $36 \pm 14 \mathrm{~Bq} \cdot \mathrm{m}^{-3}$ to $195 \pm 27 \mathrm{~Bq} \cdot \mathrm{m}^{-3}$, with an average concentration of $121 \pm 26 \mathrm{~Bq} \cdot \mathrm{m}^{-3}$. This study shows that the average summer radon concentration $\left(121 \pm 26 \mathrm{~Bq} \cdot \mathrm{m}^{-3}\right)$ for the inhabitants of the Dhirkot area was within the accepted safe health limit (radon <200 Bq.m ${ }^{-3}$, ICRP, 1993; UNSCEAR, 1993).

In the present study measurements were carried out during summer (July through September) when indoor radon concentrations are expected to be lower. However, in the winter season there is severe cold in Dhirkot and inhabitants like reduced ventilation to save heat. The lesser ventilation in winter months leads to buildup of radon inside the houses. Therefore, indoor radon concentration measurements around November through February are essential to calculate the annual effective dose in Dhirkot since the influence of the winter concentration on the dose could be larger.

The basement rocks of the Murree Formation and Kamlial Formation that occur around the dwellings have outdoor gamma dose rates of $73.9 \pm 1.4$ to $113.1 \pm 2.4 \mathrm{nGy} / \mathrm{h}$ and $69.6 \pm 2.2$ to $108.8 \pm 1.4 \mathrm{nGy} / \mathrm{h}$, respectively. The average 
INDOOR RADON CONCENTRATION, OUTDOOR GAMMA DOSE RATES

gamma dose rates for the dominant clay and subordinate sandstone sequences of the Murree and Kamlial Formations were $91.4 \pm 16.4 \mathrm{nGy} / \mathrm{h}$ and $91.1 \pm$ $14.4 \mathrm{nGy} / \mathrm{h}$, respectively. However, the dominant sandstone and subordinate clay sequence of the Kamlial Formation shows an average gamma dose rate of $95.7 \mathrm{nGy} / \mathrm{h}$. The Murree and Kamlial Formations have the average gamma dose rate of $91.3 \pm 14.3 \mathrm{nGy} / \mathrm{h}$.

The gamma dose rates showed weak positive correlation with the height of the area (Tab. I). The gamma dose rate was $113.1 \pm 2.4 \mathrm{nGy} / \mathrm{h}$ in Lawari (5539 feet) and $69.6 \pm 2.2 \mathrm{nGy} / \mathrm{h}$ in Chamiati (4493 feet) (Tab. I; Fig. 1). However, in Lahore, Pakistan, at lower altitude (800 feet), the average gamma dose rate has been reported as $65 \mathrm{nGy} / \mathrm{h}$ (Akhtar et al., 2005). The outdoor gamma dose rates in Turkey (Erees et al., 2006) and Japan (Chikasawa et al., 2001) have been reported to range from $78.3 \mathrm{nGy} / \mathrm{h}$ to $135.7 \mathrm{nGy} / \mathrm{h}$ and $13.8 \mathrm{nGy} / \mathrm{h}$ to $187 \mathrm{nGy} / \mathrm{h}$, respectively. The $69.6 \pm 2.2 \mathrm{nGy} / \mathrm{h}$ to $113.1 \pm 2.4 \mathrm{nGy} / \mathrm{h}$ gamma dose rate in the area is within the gamma dose rates of the above-mentioned countries. The gamma dose rates in the area depend on the lithology (sandstones and clays), altitude and radionuclide contributions.

The average outdoor gamma dose rate of $91.3 \pm 14.3 \mathrm{nGy} / \mathrm{h}$ in the Dhirkot area is within the world average range of 18-93 $\mathrm{nGy} / \mathrm{h}$ (UNSCEAR, 2000).

Acknowledgments. The authors are thankful to the PINSTECH, Islamabad, and the University of Azad Jammu and Kashmir, Muzaffarabad, Pakistan, for providing the laboratory and research facilities. We are thankful to the residents of dwellings in the study area who cooperated during the installation and collection of dosimeters in their houses and for their help during field work.

\section{REFERENCES}

Akhtar S.S., Wali-Ullah., Hussain A., Muhammad R. (2004) Geological map of the Dhirkot area Muzaffarabad and Bagh Districts, AJK and parts of Rawalpindi and Abbottabad Districts. Geol. Surv., Pakistan, Geol. map series 2004, 5-16.

Akhtar N., Tufail M., Ashraf M., Iqbal M.M. (2005) Measurement of Environmental Radioactivity for estimation of radiation exposure from saline soil of Lahore, Pakistan, Radiat. Meas. 39, 11-14.

Akram M., Khattak N.U., Iqbal A., Qureshi A.A., Ullah K., Qureshi I.E. (2005) Measurement of radon concentration in dwellings of Skardu city Pakistan, Radiat. Meas. 40, 695-698.

Baig M.S. (1991) Geochronology of pre-Himalayan and Himalayan tectonic events, northwest Himalaya, Pakistan, Kashmir Jour. Geol. 8-9, 197.

Baig M.S. (2006) Active faulting and earthquake deformation in Hazara-Kashmir syntaxis, Azad Kashmir, northwest Himalayas, Pakistan: Int. Sci. Conf. Earthquake in Pakistan, its implications and hazard mitigations, Islamabad, 20-21.

Baig M.S., Lawrence R.D. (1987) Precambrian to early Paleozoic orogenesis in the Himalaya, Kashmir Jour. Geol. 5, 1-22.

Chikasawa K., Ishii T., Sugiyama H. (2001) Terrestrial gamma radiation in Kochi prefecture, Japan, Jour. Health Sci. 47(4), 362-372. 
Choubey V., Sharma K.K., Ramola R.C. (1997) Geology of Radon occurrence around Jari in Parvati Valley, Himachal Pradesh,India, Jour. Environ. Radioact. 34, 139-147.

Choubey V.M., Bartarya S.K., Negi M.S., Ramola R.C. (2003) Measurement of radon and thoron concentrations in the indoor atmosphere and drinking water of eastern Doon Valley, India, Indoor Built Environ. 12, 191-196.

Deka P.C., Sarkar S., Bhattacharjee B., Goswami T.D., Sarma B.K., Ramchanran T.V. (2003) Measurement of radon and thoron concentration by using LR-115 type-plastic track detectors in the environ of Bramaputra valley, Assam, India, Radiat. Meas. 36, 431-434.

Erees F.S., Akozcan S., Parlak Y., Cam S. (2006) Assessment of dose rates around Manisa Turkey, Radiat. Meas. 41, 598-601.

Fleischer R.L., Price P.B., Walker R.M. (1975) Nuclear tracks in solids: principles and applications. University of California Press, Berkley, pp. 1-200.

Franco-Marina F., Villalba-Caloca J., Segovia N., Tavera L. (2003) Spatial indoor radon distribution in Maxico city, Sci. Tot. Environm. 317, 91-103.

ICRP publication 65 (1993) Protection against radon at home and at work, International Commission on Radiological Protection, Ann. ICRP 23 (2).

Iimoto T., Kosako T., Sugiura N. (2001) Measurement of summer Radon and its progeny concentrations along with environmental gamma dose rates in Taiwan, Jour. Environ. Radioact. 57, 57-66.

Iqbal A., Baig M.S., Akram M., Bashir A., Qureshi A.A. (2007a) Measurement of radon concentration in dwellings of Muzaffarabad city Azad Kashmir, Northwest Himalayas, Pakistan, Eur. Jour. Sci. Res. 17, 373-378

Iqbal A., Baig M.S., Akram M., Rahim S., Qureshi A.A. (2007b). Measurement of radon concentration using SSNTD in dwellings of Rawalakot area, Azad Jammu and Kashmir, sub-Himalayas, Pakistan, Eur. Jour. Sci. Res. 17, 392-398.

Iqbal A., Baig M.S., Akram M., Kazmi A., Saleem S., Qureshi A.A. (2008) Radon levels in dwellings of Mirpur, Azad Kashmir, sub-Himalayas Pakistan, Indoor Built Environ. 17, 397-402.

Kam E., Ahmet B. (2007) Environmental radioactivity measurements in Kastamonu region of northern Turkey, Appl. Radioact. Isotopes 65, 440-444.

Khan A.J. (2000) A study of indoor radon levels in Indian dwellings,influencing factors and lung cancer risks, Radiat. Meas. 32, 87-92.

Khan M.A.H., Chowdhury M.S. (2008) Radon measurements in some areas in Bangladesh, Radiat. Meas. 43, S410-S413.

Khan M.A., Iqbal M.J., Zafar M.S., Jameel K., Khan H.A. (1997) Radon Concentration measurements in the Dwellings of Gujranwala city of Pakistan, Jour. Natural Sci. Math. 37(1-2), 51-60.

Khan M.S., Naqvi A.H., Azam A. (2008) Study of indoor radon and its progeny levels in rural areas of north India using LR-115 plastic track detectors, Radiat. Meas. 43, S385-S388.

Majvorn B. (1986) Measurements of radon in dwellings with CR-39 track detectors, Nuclear Tracks 12(1-6), 763-766.

Ramola R.C., Negi M.S., Choubey V.M. (2005) Radon and thoron monitoring in the environment of Kumaun Himalayas: survey and outcomes, Jour. Environ. Radioact. 79, 85-92.

Sannapa J., Chandrashekara M.S., Satish L.A., Paramesh L., Venkataramaiah P. (2003) Study of background radiation dose in Mysore city, Karnataka State, India, Radiat. Meas. 37, 55-65.

Singh S., Mehra R., Singh K. (2005a) Seasonal variation of indoor radon in dwellings of Malwa region, Punjab, Atmos. Environ. 39, 7761-7767.

Singh S., Kumar A., Singh B. (2005b) Passive integrating radon studies for environmental monitoring in Hamirpur district, Himachal Pradesh, India using solid state nuclear track dectectors, Radiat. Meas. 39, 81-85. 
INDOOR RADON CONCENTRATION, OUTDOOR GAMMA DOSE RATES

Tufail M., Khan M.A., Ahmed N., Khan H.A., Zafar N.M. (1992) Measurements of radon concentration in some cities of Pakistan, Radiat. Prot. Dosim. 40(1), 39-44.

Tufail M., Ahmad N. (1992) Measurement of radon in some cities of Pakistan and assessment of excess lung cancer risk, Nucl. Sci. Jour. 29(4), 263-272.

UNSCEAR (1993) United Nation Scientific Committee on the Effects of Atomic radiation, United Nations, New York.

UNSCEAR (2000) United Nation Scientific Committee on the Effects of Atomic radiation Report to the General Assembly, United Nations, New York.

Vaupotic J., Krizman M., Planinic J., Pezdic J., Adamic K., Stegnar P., Kobal I. (1994) Systematic indoor radon and gamma measurements in Kindergartens and play schools in Slovenia, Health Phys. 66(5), 550-556.

Wadia D.N. (1928) The Geology of Poonch State (Kashmir) and adjacent portions of the Punjab, Mem Geol. Surv., Indian Records, 11p.

Wadia D.N. (1931) The syntaxis of the Northwest Himalaya: its rocks, tectonics and orogeny, Mem. Geol. Surv., Indian Records 65, 185-370. 